\title{
CAVITATION CORROSION AND REPASSIVATION KINETICS OF \\ TITANIUM IN A HEAVY BRINE LiBr SOLUTION EVALUATED BY USING \\ ELECTROCHEMICAL TECHNIQUES AND CONFOCAL LASER SCANNING \\ MICROSCOPY
}

Fernández-Domene, R.M., Blasco-Tamarit, E., García-García, D.M., García-

Antón, J. *

Ingeniería Electroquímica y Corrosión (IEC). Departamento de Ingeniería Química y

Nuclear. ETSI Industriales. Universidad Politécnica de Valencia. P.O. Box 22012, E46071 Valencia. Spain.

Tel.34-96-387 76 30, Fax.34-96-387 76 39, e-mail.jgarciaa@iqn.upv.es

The cavitation corrosion behaviour of commercially pure Grade 2 titanium in a $992 \mathrm{~g} / \mathrm{l}$ $\mathrm{LiBr}$ solution has been investigated at $25^{\circ} \mathrm{C}$ using an ultrasound device. Cavitation was found to have more influence on the anodic branch than on the cathodic branch, shifting the corrosion potential, $E_{c o r r}$, and the OCP value towards more negative potentials, and increasing the corrosion current density, $i_{c o r r}$, by six times.

The repassivation kinetics of Grade 2 titanium have also been studied in the $992 \mathrm{~g} / \mathrm{l}$ $\mathrm{LiBr}$ solution, at $25^{\circ} \mathrm{C}$ and various applied potentials, using cavitation to damage the electrode surface. The repassivation kinetics have been analysed in terms of the current density flowing from the area damaged by cavitation, and the results were described by the equation $i(t)=A \cdot t^{-n}$. At potentials within the passive region, the passive film grew 
according to the high-field ion conduction model in which $\log i(t)$ is linearly proportional to $1 / q(t)$. The damage generated during the potentiostatic tests has been quantified by means of Confocal Laser Scanning Microscopy.

Keywords: Titanium; Cavitation; Potentiostatic Measurements; Repassivation; Confocal Laser Scanning Microscopy.

\section{INTRODUCTION}

Stratospheric ozone depletion is increasingly recognised as a process threatening to upset the ecological support system of the Earth. In order to minimize ozone depletion, many countries have signed the Montreal Protocol (1987) and the Kyoto Protocol (1997). In accordance with these documents, CFC and HCFC fluids, which are widely used in vapour-compression refrigerators and heat pumps, will be gradually phased out. In some EU countries, this ban extends to HFC fluids [1]. The vapour-absorption cycle is considered to be the best substitute of the vapour-compression cycle in terms of energy.

Aqueous lithium bromide is used as an absorption working fluid because it is one of the best choices found among hundreds of other working fluids [1-4]. Although aqueous $\mathrm{LiBr}$ solutions are the preferred choice for many applications, they are corrosive to many metals [5-11]. Consequently, it is very important to carry out studies on the corrosion behaviour in $\mathrm{LiBr}$ media of the materials employed in the construction of $\mathrm{LiBr}$ absorption machines. The high corrosion resistance of titanium is a consequence of the stable, adherent, tenacious and permanent oxide film formed on its surface [11-14]. 
This layer protects titanium and gives it its excellent resistance to corrosion in a wide range of aggressive media, such as halide solutions. Thus, titanium corrosion resistance in $\mathrm{LiBr}$ solutions can be regarded as a reference for developing other materials with similar behaviour.

Cavitation is defined as the process of rupturing any liquid by a decrease in pressure at nearly constant temperature. Vapour cavities appear in those regions where the pressure is lower than the tensile strength of the liquid $[15,16]$. The cavities driven by the flow in a region of high pressure will implode and generate high-pressure pulses, eventually leading to erosion. Cavitation occurs in hydrodynamic systems, such as marine propellers, pumps, turbines, valves, narrowings, hydrofoils, etc.

While pure cavitation erosion occurring in non-corrosive environments is essentially a mechanical process, cavitation-erosion in a corrosive environment is complicated by the coexistence of corrosion. It is generally assumed that the combined action of electrochemical and mechanical factors will produce far more damage than if each acted separately [17-21]. This synergistic effect of corrosion and cavitation erosion has often resulted in accelerated material damage or unexpected catastrophic failure of the components during operation $[22,23]$.

Most engineering metals, such as stainless steels or titanium and titanium alloys react spontaneously in aqueous solutions to form passive films, which are responsible for their good corrosion properties. The effect of passive films on corrosion in static conditions is well known, but studies on their influence on cavitation erosion-corrosion of metals are scarce $[10,22,24-26]$. The localised impact pressures generated by the collapsing cavities [16] are sufficiently large to destroy the passive film of most metals, exposing the bare metal to the corrosive environment and thereby enhancing the 
corrosion rate. Apart from the physical damage, the collapse of cavitation bubbles induces high velocity fluid flow which is responsible for mass transfer enhancement $[10,19,23-30]$. However, there is a lack of studies on resistance of titanium and titanium alloys to cavitation-corrosion [31].

The maintenance of a low corrosion rate in a metal with passive behaviour, such as titanium, is closely related to the possibility of the passive film forming very rapidly on the surface when it has been damaged. Localised corrosion processes are generally classified into three stages of film breakdown-dissolution-repassivation, where repassivation is a film reforming process on the broken surface. The capacity of a passive metal to repassivate after breakdown determines its resistance against localised failures. The process of removal and regrowth of the passive film has been studied using several methods, including scratch [32-38], straining [39,40], instantaneous fracture [41,42], abrasion [43-47], guillotine cutting [48] or cavitation [10,49]. Reformation of the passive film was measured by recording the current that resulted when a bare surface was formed. In the present work, cavitation was used to produce film breakdown.

\section{EXPERIMENTAL PROCEDURE}

\subsection{Materials and specimen preparation}

The material tested was commercially pure Grade 2 titanium $(0.03 \% \mathrm{~N}, 0.1 \% \mathrm{C}, 0.25 \%$ $\mathrm{O}, 0.3 \% \mathrm{Fe}, 0.0125 \% \mathrm{H}$, Bal. Ti). Titanium electrodes were cylindrically shaped and covered with polytetrafluoroethylene (PTFE) coating, to expose an area of $0.5 \mathrm{~cm}^{2}$ to the test solution. The electrodes were mechanically abraded from $500 \mathrm{SiC}$ (silicon 
carbide) grit to $4000 \mathrm{SiC}$ grit, and washed with distilled water. Titanium electrodes were tested in a heavy brine $\mathrm{LiBr}$ solution (992 g/l). LiBr was supplied by PANREAC.

\subsection{Potentiodynamic tests}

Under static conditions (without cavitation) potentiodynamic polarisation curves of titanium were determined using an Autolab PGSTAT302N potentiostat. The experimental arrangement consists of two parts: a horizontal electrochemical cell $[50,51]$ with the data acquisition equipment and an image acquisition unit formed by a trinocular microscope-stereoscope (NIKON SMZ-U) zoom 1:10 and a colour video camera (SONY SSC-C370P). The image acquisition unit allows the electrode surface to be observed in real-time during potentiodynamic polarisation so as to document the events that take place on the electrode surface to the polarisation curve. The electrochemical data were measured in situ by using a three-electrode electrochemical cell composed of a silver/silver chloride reference electrode with $3 \mathrm{M}$ potassium chloride solution and a platinum mesh auxiliary electrode. All experiments were carried out at $25^{\circ} \mathrm{C}$. Before the test, the electrolyte was purged with purified nitrogen gas for 1 hour, in order to deaerate the solution. The purging continued over the electrolyte solution until the end of the potentiodynamic test.

For the tests under static conditions, after immersing the electrode in the solution, the open circuit potential value was recorded for 1 hour. Then, the electrode potential was scanned from a potential value of $-150 \mathrm{mV}$ Ag/AgCl with respect to the OCP value towards

the active direction at $0.5 \mathrm{mV} / \mathrm{s}$. Corrosion current density $\left(i_{c o r r}\right)$ and corrosion potential 
$\left(E_{c o r r}\right)$ were obtained from polarisation curves. Passivation current density $\left(i_{p}\right)$ was also determined. In all cases, the tests were repeated at least three times.

Cavitation was produced with an ultrasound device with a $550 \mathrm{~W}$ output power, a 20 $\mathrm{kHz}$ output frequency and a peak-to-peak amplitude (ppA) of $120 \mu \mathrm{m}$. The horn tip was $12.7 \mathrm{~mm}$ in diameter. The specimen was placed co-axially to the horn, and was held static at a distance of $10 \mathrm{~mm}$ from the horn tip (Figure 1). Nitrogen was bubbled for 1 hour before and during the test in order to remove the oxygen present in the system. Prior to each anodic polarisation scan, the open circuit potential value without cavitation was registered for $55 \mathrm{~min}$. When the vibratory device was connected, the open circuit potential value was measured for $5 \mathrm{~min}$. Potentiodynamic polarisation started from a potential of $-150 \mathrm{mV}$ Ag/AgCl with respect to the OCP value with cavitation towards the anodic direction, at a fixed rate of $0.5 \mathrm{mV} / \mathrm{s}$. In order to protect the horn of the ultrasound device, the potentiodynamic polarisation curve under cavitation conditions was performed up to $0.5 \mathrm{~V}_{\mathrm{Ag} / \mathrm{AgCl}}$. The temperature was maintained at $25^{\circ} \mathrm{C}$.

The morphological inspection of the electrodes surface after potentiodynamic polarisation was done by using a Confocal Laser Scanning Microscope (CLSM), which uses the LEXT OLS 6.0.3 software. The CSLM is equipped with a Laser Diode with a wavelength of $408 \mathrm{~nm}$, an outstanding horizontal resolution of $0.22 \mu \mathrm{m}$, vertical resolution of $0.01 \mu \mathrm{m}$ (z-axis), and a magnification range from $120 \mathrm{x}$ to $14400 \mathrm{x}$.

\subsection{Potentiostatic tests}


The device shown in Figure 1 was also used in the repassivation tests. The horn tip had a diameter of $3.2 \mathrm{~mm}$, to cause more localised damage. A gap on $1 \mathrm{~mm}$ was left between the working electrode and the horn tip when cavitation was applied on the electrode surface, so as to produce more concentrated damage.

The potentiostatic tests were carried out at six different applied potentials $(0.1,0.30 .5$, $1,1.5$ and $\left.2 \mathrm{~V}_{\mathrm{Ag} / \mathrm{AgCl}}\right)$. In order to reach the potential applied during the potentiostatic test, the potential was reduced to $-300 \mathrm{mV}_{\mathrm{Ag} / \mathrm{AgCl}}$ in four potentiostatic steps of 15 seconds each, and then was swept at $0.5 \mathrm{mV} / \mathrm{s}$ from $-300 \mathrm{mV}_{\mathrm{Ag} / \mathrm{AgCl}}$ to the chosen potential. When the selected potential was reached, it was held for 1 minute under static conditions. Then, cavitation was switched on for another minute. After that, the potentiostatic test continued for 1 extra hour at the selected potential, with cavitation disconnected. The current recorded during this hour without cavitation was then used to study repassivation kinetics. The tests were conducted at $25^{\circ} \mathrm{C}$, and the solution was deaerated with purified nitrogen for 1 hour prior to and during the experiments. The tests were repeated at least three times.

During the whole potentiostatic test, the resulting change in current was recorded the constant applied potential. The transient obtained just after disconnecting cavitation was used to obtain the repassivation index, $n$, from the downward slope of the logarithmic representation $\log i(\mathrm{t})$ vs. $\log t$, as well as other parameters, such as the repassivation time, $t_{r}$, and the slope of the representation $\log i(t)$ vs. $1 / q(t)$ (the $c V B$ parameter, which can also be an effective measure of the repassivation rate). Once the test finished, the electrodes were rinsed with distilled water to quantify the generated damage by using Confocal Laser Scanning Microscopy (CLSM). 
Finally, a cavitation-erosion test using distilled water was carried out following the same procedure, but without applying any potential. The resulting damage was also quantified by using the Confocal Laser Scanning Microscope, in order to compare the results in water (physical damage only) and in the $\mathrm{LiBr}$ solution.

\section{RESULTS AND DISCUSSION}

\subsection{Potentiodynamic tests}

\subsubsection{OCP (Open Circuit Potential)}

The effect of cavitation on the open circuit potential (OCP) for titanium in the $992 \mathrm{~g} / \mathrm{l}$

$\mathrm{LiBr}$ solution is shown in Table 1. It can be observed that the OCP value shifted towards more negative potentials by almost $1000 \mathrm{mV}_{\mathrm{Ag} / \mathrm{AgCl}}$ when cavitation was present. This displacement observed in the OCP measurement caused by cavitation agrees with the work of other authors $[10,17,19,24,28]$. The rapid negative shift of the OCP value could be explained in terms of destruction of the passive film and formation of fresh metal surfaces as a result of the collapsing bubbles. However, after the OCP test with cavitation, the electrode examination revealed no damage on its surface (Figure 2). Thus, the negative shift under cavitation does not mean that titanium was actively corroding, but that the metal surface was covered with a passive film which was thinner than that under static condition $[10,17,25]$.

\subsubsection{Potentiodynamic polarisation curves}


Figure 3 shows the potentiodynamic polarisation curves of titanium in the $992 \mathrm{~g} / \mathrm{L} \mathrm{LiBr}$ solution under static and cavitation conditions and Figure 4 shows images of the electrode surface taken in situ under static conditions at different times during the potentiodynamic test, with the image acquisition unit. Table $\mathbf{2}$ presents the electrochemical parameters under both conditions. It can be seen that under static conditions, current density values are very small, lower than $2 \mu \mathrm{A} / \mathrm{cm}^{2}$ in a wide range of potentials (from $200 \mathrm{mV}_{\mathrm{Ag} / \mathrm{AgCl}}$ until $700 \mathrm{mV}_{\mathrm{Ag} / \mathrm{AgCl}}$ approximately), which can be regarded as a passive zone (the mean value of $i_{p}$ is $1.94 \mu \mathrm{A} / \mathrm{cm}^{2}$, Table 2). This good behaviour of titanium against corrosion is a consequence of the formation of a stable, adherent, tenacious and permanent oxide film on its surface [11-14], which is highly resistant to various aggressive environments. According to several authors $[14,52,53]$ this passive film consists mainly of amorphous $\mathrm{TiO}_{2}$, although mixtures of other titanium oxides including $\mathrm{TiO}, \mathrm{Ti}_{2} \mathrm{O}_{3}$ and $\mathrm{TiO}_{2}$ may be present [53].

During the potentiodynamic test it was noticeable that, at $950 \mathrm{mV}_{\mathrm{Ag} / \mathrm{AgCl}}$, the colour of the solution around the titanium electrode surface changed from colourless to yelloworange (Figure 4b-d); this change in colour is related to the localised oxidation of bromides ions to bromine $\left(\mathrm{Br}_{2}\right)$ at electroactive sites and to the subsequent formation of $\mathrm{HBrO}$, according to the following equations [54]:

$$
\begin{gathered}
2 \mathrm{Br}^{-} \Leftrightarrow \mathrm{Br}_{2}+2 e^{-} \\
\mathrm{Br}_{2}+\mathrm{H}_{2} \mathrm{O} \rightarrow \mathrm{HBrO}+\mathrm{Br}^{-}+\mathrm{H}^{+}
\end{gathered}
$$


Many studies regarding the electrochemical behaviour of titanium in bromide solutions have reported the oxidation of $\mathrm{Br}^{-}$to $\mathrm{Br}_{2}$ at potentials around $1 \mathrm{~V}_{\mathrm{Ag} / \mathrm{AgCl}}$ [55-57]. This oxidation reaction may explain the rise in current density from 800 to $1.2 \mathrm{~V}_{\mathrm{Ag} / \mathrm{AgCl}}$.

At about $1.3 \mathrm{~V}_{\mathrm{Ag} / \mathrm{AgCl}}$ the formation of the first electrogenerated oxygen bubbles was perceptible on the titanium surface (Figure 4c). These oxygen bubbles formed as a consequence of the oxygen evolution reaction (OER):

$$
2 \mathrm{H}_{2} \mathrm{O} \Leftrightarrow \mathrm{O}_{2}+4 \mathrm{H}^{+}+4 e^{-}
$$

The formation of oxygen bubbles has also been reported when polarising titanium above 1.3-1.4 $\mathrm{V}_{\mathrm{Ag} / \mathrm{AgCl}}[5,11,55,58]$. Hence, the high current density values recorded beyond $1.2 \mathrm{~V} \mathrm{Ag} / \mathrm{AgCl}$ could be explained by the oxygen evolution reaction.

At higher potentials (about 1.5 and $1.9 \mathrm{~V} \mathrm{Ag} / \mathrm{AgCl}$ ), two current density peaks can be observed in the polarisation curve (Figure 3). According to several authors $[5,11,53,59]$, these peaks are related to the oxidation of $\mathrm{TiO}$ and $\mathrm{Ti}_{2} \mathrm{O}_{3}$ to $\mathrm{TiO}_{2}$, respectively. The maximum current density was reached at $1.5 \mathrm{~V} \mathrm{Ag} / \mathrm{AgCl}\left(2.78 \mathrm{~mA} / \mathrm{cm}^{2}\right)$ decreasing slightly after this value.

Above $2 \mathrm{~V}_{\mathrm{Ag} / \mathrm{AgCl}}, \mathrm{TiO}_{2}$ could be further oxidised to soluble complex species, such as $\mathrm{TiO}^{2+}[60]$. Thus, the current density associated with the oxidation of titanium species contributed considerably to the total current density, adding to that attributable to the 
oxygen and bromine evolution reactions. At those potentials, current density decreased slightly until reaching a constant value of $0.841 \mathrm{~mA} / \mathrm{cm}^{2}$.

Although the current density value of $100 \mu \mathrm{A} / \mathrm{cm}^{2}$ was reached during the potentiodynamic polarisation under static conditions (this value is considered to set the beginning of pitting corrosion $[5,11,61,62])$, no damage was observed on the titanium surface after the test (Figure 4e), so the oxide film could still protect titanium from undergoing active corrosion even at $3 \mathrm{~V}_{\mathrm{Ag} / \mathrm{AgCl}}$ in the $992 \mathrm{~g} / 1 \mathrm{LiBr}$ solution at $25^{\circ} \mathrm{C}$. The titanium surface kept the same luster as before the test, although it was possible to distinguish a multicoloured surface (unnoticeable in the CLSM images), as a consequence of the formation of the oxide film [11]. In a previous work [11] it was also demonstrated that in highly concentrated $\mathrm{LiBr}$ solutions $(700$ and $850 \mathrm{~g} / \mathrm{LiBr}, 8.06 \mathrm{M}$ and $9.78 \mathrm{M}$, respectively), titanium did not undergo pitting corrosion even at $3 \mathrm{~V}_{\mathrm{Ag} / \mathrm{AgCl}}$, confirming the results obtained in the present work, where bromide concentration is higher.

It can be concluded that the high current densities recorded above $700 \mathrm{mV}_{\mathrm{Ag} / \mathrm{AgCl}}$ were related to several oxidation processes $\left(\mathrm{Br}^{-}\right.$oxidation, $\mathrm{O}_{2}$ evolution reaction and oxidation of titanium oxides) rather than to the active corrosion of titanium surface.

In order to explain the influence of cavitation on the corrosion behaviour of a metal, two tendencies must be taken into account [19,22,24,28,29]: on the one hand, the mechanical action of cavitation can destroy the passive film formed on the electrode surface or reduce its thickness, thereby generating fresh surface and favouring metal 
corrosion; on the other hand, cavitation stirs the solution, increasing the amount of oxidant species supplied to the surface and enhancing the cathodic reaction rate.

Cavitation has more influence on the anodic branch than on the cathodic branch (Figure $3)$, so the $E_{\text {corr }}$ value is much more negative under cavitation conditions (-1248 $\mathrm{mV}$ ) than under static conditions $(-149 \mathrm{mV})$, and the corrosion current density, $i_{\text {corr }}$, is about six times higher under cavitation conditions than under static conditions $\left(1.14 \mu \mathrm{A} / \mathrm{cm}^{2}\right.$ and $0.2 \mu \mathrm{A} / \mathrm{cm}^{2}$, respectively). A passive region was also observed under cavitation conditions up to $0.3 \mathrm{~V}_{\mathrm{Ag} / \mathrm{AgCl}}$, where the passive current density, $i_{p}$, also increased by the effect of cavitation $\left(1.94 \mu \mathrm{A} / \mathrm{cm}^{2}\right.$ without cavitation and $2.94 \mu \mathrm{A} / \mathrm{cm}^{2}$ with cavitation, Table 2). Other authors obtained similar results for titanium in saline media [31].

The increase in $i_{p}$ under cavitation conditions could be related to the thinning of the passive film formed on the electrode surface due to the action of cavitation $[10,25]$, but not due to film breakdown, since the electrode surface showed no damage after the potentiodynamic test (Figure 5). This was further supported by the fact that the OCP value of titanium under cavitation conditions was still in the passive range. This rise of $i_{p}$ when cavitation was present could also be associated with the thickness of the diffusion layer [24]. Corrosion of metals usually leads to formation of dissolved metal ions at the corroding surface and the subsequent formation of a solid film through which ions must migrate, dissolving into the solution. Under static conditions, the thickness of this film did not change and its rate of formation by metal oxidation at the film $/ \mathrm{metal}$ interface equals its rate of dissolution at the film/solution interface [24]. Since dissolution is mass transport controlled, a limiting current is observed given by: 


$$
i_{\lim }=\frac{z F D_{M}\left(C_{M, s a t}-C_{M, b}\right)}{\delta}
$$

where $D_{M}$ is the diffusion coefficient of the metal ion, $F$ is Faraday's constant, $z$ is the number of electrons transferred for an ion, $C_{M \text {,sat }}$ is the saturation concentration of the transport limiting metal cation, $C_{M, b}$ is the metal ion concentration in the bulk solution, and $\delta$ is the thickness of the diffusion layer. Under cavitation conditions the implosion of bubbles near the surface produces a decrease of $\delta$, which makes the $i_{\text {lim }}$ value increase, consequently increasing the value of the passive current density, $i_{p}$.

\subsection{Repassivation behaviour}

\subsubsection{Linear curves current density (i) vs. time (t)}

In order to study the effect of applied potential on the repassivation kinetics of titanium in a deaerated $992 \mathrm{~g} / 1 \mathrm{LiBr}$ solution, six anodic potentials were selected $(0.1,0.3,0.5,1$, 1.5 and $2 \mathrm{~V}_{\mathrm{Ag} / \mathrm{AgCl}}$ ). Figures 6(a) and 6(b) give the current density transients on a linear scale for the first 20 seconds of repassivation. It was necessary to establish the time zero, which was set as that time at which cavitation was switched off and repassivation started. Figure 6(b) shows an enlargement of the current density transients for the tests performed at $0.1,0.3,0.5$ and $1 \mathrm{~V}_{\mathrm{Ag} / \mathrm{AgCl}}$. Potentials 0.3 and $0.5 \mathrm{~V}_{\mathrm{Ag} / \mathrm{AgCl}}$ are located within the passivity region of titanium (Figure 3) in which current density values did not exceed $2 \mu \mathrm{A} / \mathrm{cm}^{2}$; the values of 0.1 and $1 \mathrm{~V}_{\mathrm{Ag} / \mathrm{AgCl}}$ are not located in this passive region (the potential of $0.1 \mathrm{~V}_{\mathrm{Ag} / \mathrm{AgCl}}$ belongs to the zone previous to that of passivity, and the potential of $1 \mathrm{~V}_{\mathrm{Ag} / \mathrm{AgCl}}$ is located beyond the passive zone), although current densities at these two potentials were also rather small, lower than $10 \mu \mathrm{A} / \mathrm{cm}^{2}$; the last 
two potentials (1.5 and $2 \mathrm{~V} \mathrm{Ag} / \mathrm{AgCl})$ are placed in the region above $1 \mathrm{~V}_{\mathrm{Ag} / \mathrm{AgCl}}$, where current density values are higher than $100 \mu \mathrm{A} / \mathrm{cm}^{2}$.

Current density was obtained from the current transients recorded during the potentiostatic tests and the amount of damage generated on the electrode surface, which was quantified by Confocal Laser Scanning Microscopy. The anodic current measured during the repassivation process was assumed to originate from two anodic processes. One is the metal dissolution reaction and the other is repassivation, that is, an oxidation reaction of titanium with water to form the passive film. When passive films are formed, the dissolution current is usually very small, unless metal dissolution is dominated by pitting or general corrosion $[32,36,39,40]$; therefore it is assumed that current density due to metal dissolution at both ruptured and unruptured film sites is insignificant compared to that of repassivation.

The passive film previously formed on the titanium electrode surface was broken when cavitation was connected, leading to an abrupt increase in current density because of the anodic oxidation reaction of the bare metal surface. Current density peak values increased as the applied potential increased (Figures 6(a) and 6(b)), indicating a higher oxidation tendency of the bare metal at higher potentials, with the exception $1.5 \mathrm{~V} \mathrm{Ag} / \mathrm{AgCl}$ potential. At this potential, the current density value in the potentiodynamic curve (Figure 3) is higher than at $2 \mathrm{~V}_{\mathrm{Ag} / \mathrm{AgCl}}$, as it has been mentioned above when describing the potentiodynamic polarisation curves, so current density is expected to be higher at $1.5 \mathrm{~V}_{\mathrm{Ag} / \mathrm{AgCl}}$ than at $2 \mathrm{~V}_{\mathrm{Ag} / \mathrm{AgCl}}$ in the potentiostatic test. 
In Figure 6(b), the anodic current density at $0.1,0.3,0.5$ and $1 \mathrm{~V}_{\mathrm{Ag} / \mathrm{AgCl}}$ decreased with time just after interrupting cavitation as repassivation proceeds, reaching a stationary value which remained stable until the end of the potentiostatic test. At the highest potentials (1.5 and $2 \mathrm{~V}_{\mathrm{Ag} / \mathrm{AgCl}}$ ), current density suddenly increased just after switching off cavitation (Figure 6(a)), which means that the titanium surface did not repassivate, even after 1 hour. At the end of the test, the current density at $1.5 \mathrm{~V}_{\mathrm{Ag} / \mathrm{AgCl}}$ reached a stable value of $8.7 \mathrm{~mA} / \mathrm{cm}^{2}$ whereas at $2 \mathrm{~V} \mathrm{Ag} / \mathrm{AgCl}$, this stable value was $0.87 \mathrm{~mA} / \mathrm{cm}^{2}$, ten times lower than at $1.5 \mathrm{~V}_{\mathrm{Ag} / \mathrm{AgCl}}$. As it has been described previously, these high values of current density are related to several oxidation processes $\left(\mathrm{Br}^{-}\right.$oxidation, $\mathrm{O}_{2}$ evolution reaction and oxidation of titanium oxides).

The repassivation rate of a metal or alloy can be compared in terms of the time required to achieve the predetermined degree of repassivation after damaging the electrode surface, which is known as repassivation time $[35,36]$. The shorter the repassivation time, the faster the repassivation rate of an alloy will be. As it can be seen in Figure 6(b), in general it takes a shorter time for titanium to repassivate to an arbitrary degree of repassivation $\left(i_{r}=5 \cdot 10^{-5} \mathrm{~A} / \mathrm{cm}^{2}\right.$, similar to the values existing before connecting cavitation) when the applied potential is lower $\left(t_{0.1} \approx t_{0.3}<t_{0.5}<t_{1}\right.$, Table 3). Since $t_{0.1}$ and $t_{0.3}$ were lower than the rest of the repassivation times, titanium repassivated more rapidly at these potentials than at 0.5 and $1 \mathrm{~V}_{\mathrm{Ag} / \mathrm{AgCl}}$. At $1 \mathrm{~V}_{\mathrm{Ag} / \mathrm{AgCl}}$ it took more than 15 seconds for current density to reach the arbitrary $i_{r}$ value, and at $1.5 \mathrm{~V}_{\mathrm{Ag} / \mathrm{AgCl}}$ and 2 $\mathrm{V}_{\mathrm{Ag} / \mathrm{AgCl}}$ (Figure 6(a)) titanium did not repassivate at any time. Thus, it can be inferred that the repassivation rate of titanium in the $992 \mathrm{~g} / \mathrm{l} \mathrm{LiBr}$ solution decreases as the applied potential increases (for those potentials between 0.1 and $1 \mathrm{~V}_{\mathrm{Ag} / \mathrm{AgCl}}$ ). 


\subsubsection{Logarithmic curves $\log i(t) v s . \log t$}

According to several authors $[32,33,39,48]$, the damaged surface of titanium repassivates following an empirical equation, which can be written as:

$$
i(t)=A \cdot t^{-n}
$$

where $i(t)$ is the anodic current density consumed in the rebuilding of the passive film at time $t$ after switching cavitation off, $A$ is a constant and exponent $n$ is the repassivation index and gives an indication of how fast the passive film is building up. This parameter can be obtained from the slopes of the straight lines in a $\log i$ vs $\log t$ representation:

$$
\log i(t)=\log A-n \cdot \log t
$$

Current density transients on double logarithmic scale are shown in Figure 7 for titanium in the $992 \mathrm{~g} / \mathrm{l} \mathrm{LiBr}$ solution, in accordance with the relationship in Eq. (5). In all these transients, the current density $i(t)$ is the difference between the instantaneous current density, $i_{m}$, and the background current density existing before damaging the electrode surface with cavitation, $i_{s}$. The value $t=0$ was taken just after interrupting cavitation, when the repassivation process began.

According to the different slopes of each curve, three different stages can be distinguished in the curves of Figure 7 for those potentials within the passive range of titanium in the $992 \mathrm{~g} / 1 \mathrm{LiBr}$ solution, namely 0.3 and $0.5 \mathrm{~V}_{\mathrm{Ag} / \mathrm{AgCl}}$, as well as 0.1 and 1 $\mathrm{V}_{\mathrm{Ag} / \mathrm{AgCl}}$. Other authors also observed three different stages for austenitic stainless steels $[10,43]$ and for aluminium and its alloys [42,47,67], titanium and zirconium [42], and 
iron [68]. At these four potentials, the anodic current density of the first stage was almost constant, indicating that the rate of oxide formation equalled the rate of oxide destruction, so it can be said that the direct formation of a compact oxide film on the bare surface of titanium according to the following reaction:

$$
\mathrm{Ti}+2 \mathrm{H}_{2} \mathrm{O} \rightarrow \mathrm{TiO}_{2}+4 \mathrm{H}^{+}+4 e^{-}
$$

did not occur in the early stage of repassivation. In the second stage, current density decreased linearly with time for the four potentials mentioned above $(0.1,0.3,0.5$ and 1 $\mathrm{V}_{\mathrm{Ag} / \mathrm{AgCl}}$; the drop of anodic current density can be explained by the fact that the repassivation rate of the passive film dominated over its destruction rate. This second stage corresponds to the immediate repassivation of the bare surface formed by cavitation, so it was chosen to calculate parameter $n$. The rate of repassivation gradually slowed down with time within the third stage, probably due to the gradual reduction of the exposed area of bare metal [35]. The growth continued until the passive film was completely formed. In this third stage, current density was visibly distorted by the high frequency noise, which appears to be of large amplitude at low current densities $[48,69]$. Park et.al. [43] observed similar fluctuations at the later third stage for type 316L stainless steel, and they attributed metastable pitting events originated below the pitting potential for these fluctuations. However, it has been proved that titanium did not undergo pitting corrosion in the $992 \mathrm{~g} / \mathrm{l} \mathrm{LiBr}$ solution, even at potentials as high as 3 $\mathrm{V}_{\mathrm{Ag} / \mathrm{AgCl}}$, so these fluctuations are more likely to be caused by high frequency noise than by metastable pitting events. Thus, from the curves shown in Figure 7 at $0.1,0.3,0.5$ and $1 \mathrm{~V}_{\mathrm{Ag} / \mathrm{AgCl}}$ in the $992 \mathrm{~g} / \mathrm{LiBr}$ solution, it can be said that the new titanium surfaces 
repassivate continuously and completely, in accordance with the results obtained for the repassivation time (Figure 6(b)).

At higher potentials (1.5 and $\left.2 \mathrm{~V}_{\mathrm{Ag} / \mathrm{AgCl}}\right)$, placed beyond the passive zone of titanium in the $992 \mathrm{~g} / \mathrm{l} \mathrm{LiBr}$ solution, there are also three different stages in Figure 7. In the first stage (Stage 1), the slope of the $\log i$ vs. $\log t$ plot was nearly zero, like at the other applied potentials. Nevertheless, after an induction time, the current density began increasing linearly with time (Stage 2). The exposure of the bare surface to the electrolyte after damaging the electrode with cavitation favoured the generation of electroactive sites, which could explain the rise in current density due to the enhancement of the oxidation processes described above. After this linear increase, there was a sharp rise of current density, followed by a decrease with time (Stage 3), although this gradual decline of current density is so slow at these applied potentials that it did not reach the passive state. After 3600 seconds, current density was 8.73 $\mathrm{mA} / \mathrm{cm}^{2}$ and $4.78 \mathrm{~mA} / \mathrm{cm}^{2}$ at $1.5 \mathrm{~V} \mathrm{Ag} / \mathrm{AgCl}$ and $2 \mathrm{~V}_{\mathrm{Ag} / \mathrm{AgCl}}$, respectively, values which are far higher than any passive state, and clearly associated with oxidation processes [48]. Thus, although current density continuously decayed with time, there was no practical repassivation at these high potentials. Moreover, at high electrode potentials, the current density flowing through the filmed electrode surface (that is, the surface that was not damaged by cavitation) can no longer be ignored, since it significantly contributed to the total current density [69].

Based on Eq. (5), the repassivation index $n$ has been determined from the linear regions (stage 2) in Figure 7, at the applied potentials of $0.1,0.3,0.5$ and $1 \mathrm{~V}_{\mathrm{Ag} / \mathrm{AgCl}}$. The obtained values are given in Table 4. The value of $n$ changed with increasing applied 
potentials in the same way as the repassivation time did, that is, $n$ decreased as the

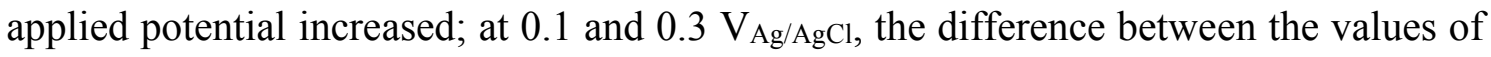
$n$ are very small, so it can be said that the repassivation rate at these potentials is similar, following the same tendency observed for the repassivation time, $t_{r}$. Values close to unity are typical for passive films growing without the superimposed destruction of passive films, and indicate the formation of a solid and compact film [39,44,67]. This type of slope $n \approx 1$ is typical of the high field formation reaction $[32,37,39,70]$, which was a model developed by Cabrera and Mott [71]. According to this model, the passive film grows by the transport of metal ions across the film towards the film/electrolyte interface under high electric fields of a few megavolts per centimetre. A mechanism of film formation with a slope of 1 was also described by Sato and Cohen [72] for iron in borate solutions. Thus, at applied potentials of $0.1,0.3$ and $0.5 \mathrm{~V}_{\mathrm{Ag} / \mathrm{AgCl}}$, repassivation was fast and took place through the growth of a highly protective passive film on the bare surface of titanium by a high field mechanism, as other authors reported for this metal $[41,42]$, or by a place exchange process. It is noteworthy that values of $n$ for potentials of 0.1 and $0.3 \mathrm{~V}_{\mathrm{Ag} / \mathrm{AgCl}}$ are a little higher than unity. Although the theoretical values of $n$ should not be greater than 1 [40], in practice several authors have considered that values of $n$ slightly higher than unity could also be properly explained by a high field mechanism $[32,36,73]$. On the other hand, at $1 \mathrm{~V}_{\mathrm{Ag} / \mathrm{AgCl}}$, the value of $n$ was about 0.5 , which is usually attributed to a porous film which grows by a dissolutionprecipitation process [39].

As it has been pointed out above, the slope of the $\log i$ vs $\log t$ plot changed in the third stage; at 0.1 and $0.3 \mathrm{~V}_{\mathrm{Ag} / \mathrm{AgCl}}$, the slope changed from approximately 1 to 0.5 ; at 0.5 $\mathrm{V}_{\mathrm{Ag} / \mathrm{AgCl}}$, this slope changed from approximately 0.8 to 0.3 , and at $1 \mathrm{~V}_{\mathrm{Ag} / \mathrm{AgCl}}$, the slope 
changed from around 0.5 to 0.17 . Thus, at $0.1,0.3$ and $0.5 \mathrm{~V}_{\mathrm{Ag} / \mathrm{AgCl}}$, an initial part of the high field film growth mechanism (in the second stage) is followed by a mechanism of dissolution and precipitation, while at $1 \mathrm{~V}_{\mathrm{Ag} / \mathrm{AgCl}}$, the film grows by a dissolutionprecipitation process in the second stage and scarcely grows within the third stage. Carranza at. al. also obtained changes in the value of $n$ (from 1 to 0.5 ) for type 304 stainless steel in $1 \mathrm{M} \mathrm{HCl}$ solution [39].

\subsubsection{Charge density calculation}

Based on the current density-time curves in Figure 6, the charge density $q(t)$ due to the damage generated on the titanium surface was calculated as:

$$
q(t)=\frac{1}{S} \int_{t=0}^{t}\left(I_{m}-I_{s}\right) \cdot d t
$$

where $\mathrm{S}$ is the value of the surface damaged by cavitation, $I_{m}$ is the current measured during repassivation, and $I_{s}$ is the background current existing before damaging the electrode surface. The value $t=0$ was taken just after interrupting cavitation, when the repassivation process began. Following the procedure used by other researchers $[32,73,74]$, the charge that passed through the external circuit $Q$ was assumed to be equal to the charge that passed through the damaged surface.

Since repassivation takes place by a nucleation and growth process of the passive film on the bare surface of the metal or alloy, those mechanisms proposed for the formation of a passive film can be applied to repassivation kinetics. The repassivation behaviour 
of titanium has been interpreted by several investigators in terms of the high-field ion conduction model $[41,42,75]$, in which $\log i(t)$ is linearly proportional to $1 / q(t)$. For those applied potentials at which the values of $n$ are near unity $(0.1,0.3$ and 0.5 $\left.\mathrm{V}_{\mathrm{Ag} / \mathrm{AgCl}}\right), \log i(t)$ vs $1 / q(t)$ plots have been drawn according to the following equation $[32,36-38,73,76]$, assuming that all the anodic charge that flows from the damaged surface actually results in film formation, that is, there is no dissolution of the metal during film formation $[32,73]$ :

$$
\log i(t)=\log A+\frac{c B V}{q(t)}
$$

where $A$ and $B$ are constant parameters associated with the activation energy of the mobile ion in the film, $c$ is a constant value for a given metal or alloy and $V$ is the potential drop across the film.

As shown in Figure 8, the repassivation of titanium in the $992 \mathrm{~g} / \mathrm{l} \mathrm{LiBr}$ solution at the these applied potentials $\left(0.1,0.3\right.$ and $\left.0.5 \mathrm{~V}_{\mathrm{Ag} / \mathrm{AgCl}}\right)$ seems to occur in three steps with different kinetics, similarly to other authors' results [37,76]:

- Step 1: The passive film barely grew before 100 msec since cavitation was switched off, obtaining a more or less horizontal slope, slightly curved, in the $\log i(t)$ vs $1 / q(t)$ plot. This step corresponds to the first stage in Figure 7.

- Step 2: The passive film grew from $100-300 \mathrm{msec}$ according to the high-field ion conduction model, in which $\log i(t)$ is linearly proportional to $1 / q(t)$. This step coincides with the second stage in Figure 7. 
- Step 3: After $300 \mathrm{msec}$, the curve deviated from the linear tendency and current density decreased slowly (stage 3 in Figure 7), which indicates that the passive film growth rate was slowing down until reaching a steady state $[73,76]$.

The value of the slope in the $\log i(t)$ vs $1 / q(t)$ plots, i.e. the $c B V$ parameter, can be an effective measure of the repassivation rate for stainless steels [36,37]. Specifically, the lower the value of $c B V$ for a given metal-environment system, the faster the repassivation of the metal or alloy is achieved through formation of a more protective film. Table 5 presents the values of the $c B V$ parameter for titanium at $0.1,0.3$ and 0.5 $\mathrm{V}_{\mathrm{Ag} / \mathrm{AgCl}}$ in the $992 \mathrm{~g} / \mathrm{LiBr}$ solution, calculated from the slope of Step 2 in the $\log i(t) \mathrm{vs}$ $1 / q(t)$ plots. It is observed that the tendency is similar to that obtained for the repassivation index $n$ (Table 4). The increase in $c B V$ was associated with a reduction of the activation energy for ion movement through the passive film and the decrease in the resistance of the passive film as a barrier for ion diffusion $[36,76]$. Thus, within the passive region, titanium exhibits its better repassivation behaviour at 0.1 and 0.3 $\mathrm{V}_{\mathrm{Ag} / \mathrm{AgCl}}$; at $0.5 \mathrm{~V} \mathrm{Ag} / \mathrm{AgCl}$, repassivation is slightly slower, confirming the results obtained before. This result implies that the $c B V$ value, a measure of the repassivation rate of stainless steels, can also be applied to titanium in the $992 \mathrm{~g} / \mathrm{L} \mathrm{LiBr}$ solution at those potentials at which repassivation kinetics follow a high field mechanism $(0.1,0.3$ and $0.5 \mathrm{~V}_{\mathrm{Ag} / \mathrm{AgCl})}$.

As it has been commented above, the anodic current measured during repassivation is consumed mostly to rebuild the passive film on the damaged surface $[32,36,39,40]$. Thus, by neglecting the current associated with metal dissolution, the charge density 
$q(t)$ that flowed from the damaged surface during repassivation has the following relationship with the film thickness $h(t)$, given by Faraday's law:

$$
q(t)=\frac{z F \rho}{M} \cdot h(t)
$$

Where $\mathrm{z}$ is the number of electrons transferred for an ion (4 for titanium, eq. (3)), $\mathrm{F}$ is the Faraday constant $(96485.34 \mathrm{C} / \mathrm{mol}), \rho$ is the film density $\left(\mathrm{TiO}_{2}\right.$ density, $4.26 \mathrm{~g} / \mathrm{cm}^{3}$ [77]) and $\mathrm{M}$ is the molecular weight of the film (79.86 $\mathrm{g} / \mathrm{mol}$ for $\left.\mathrm{TiO}_{2}\right)$. Calculated values of $q$ and $h$ for titanium in the $992 \mathrm{~g} / \mathrm{L} \mathrm{LiBr}$ after 40 seconds since the beginning of repassivation (observing Figure $\mathbf{6 b}$, the authors considered that after 40 seconds, the steady state values, $q_{\infty}$ and $h_{\infty}$, were reached) are given in Table 6 at the four potentials at which repassivation occurs, namely $0.1,0.3,0.5$ and $1 \mathrm{~V}_{\mathrm{Ag} / \mathrm{AgCl}}$. The thickness of a monolayer can be calculated as [42]:

$$
h_{m}=\left(\frac{M}{\rho \cdot N_{A}}\right)^{1 / 3}
$$

in which $N_{A}$ is Avogadro's number. For titanium, the value of $h_{m}$ is $0.31 \mathrm{~nm}$. The apparent number of molecular layers of oxide is $\mathrm{h}_{\infty} / \mathrm{h}_{\mathrm{m}}$. This value has also been included in Table 6.

As it was expected, the higher the applied potential, the higher the total charge density consumed in the rebuilding of the passive film and the thicker the new passive film formed on the damaged surface, except for the test at $0.1 \mathrm{~V}_{\mathrm{Ag} / \mathrm{AgCl}}$, where the charge density involved in the repassivation process was slightly higher than at $0.3 \mathrm{VAg} / \mathrm{AgCl}$, although the difference is not significant. 


\subsubsection{Damage quantification}

The extent of damage generated on the titanium surface by cavitation-corrosion has been quantified at the six applied potentials. Damage was estimated by using a Confocal Laser Scanning Microscope Olympus LEXT OLS3100.

By way of illustration, the pictures of the damage generated by cavitation-corrosion on the titanium surface in the $992 \mathrm{~g} / 1 \mathrm{LiBr}$ solution at $0.1,1,1.5 \mathrm{~V}_{\mathrm{Ag} / \mathrm{AgCl}}$ and in distilled water are shown in Figure 9 (at the other potentials, 0.3, 0.5 and $2 \mathrm{~V}_{\mathrm{Ag} / \mathrm{AgCl}}$, the damage produced on the electrodes surface was very similar). Table 7 shows the values of the volume, the area and the maximum depth of damage in the $992 \mathrm{~g} / \mathrm{L} \mathrm{LiBr}$ solution at the six applied potentials and in distilled water. It can be observed that no measure of the damage generated by cavitation-corrosion in the $992 \mathrm{~g} / 1 \mathrm{LiBr}$ solution seems to be influenced by the applied potential, since their order of magnitude is similar. Besides, these results are similar to those obtained for the test performed in distilled water (physical damage only), which indicates that the damages observed on the electrode surfaces after the potentiostatic tests were mainly physical damages due to cavitation. In addition, the almost circular symmetry of these damages is expected from erosion due to cavitation bubble collapse on metal surfaces [49,78-81]. This fact could be explained by the absence of pitting corrosion, since in the test conditions titanium did not experience localised attacks and the physical damage did not spread.

At 1.5 and $2 \mathrm{~V}_{\mathrm{Ag} / \mathrm{AgCl}}$, current density values are rather high, but these results do not indicate that titanium experiences active corrosion in the $992 \mathrm{~g} / 1 \mathrm{LiBr}$ at $25^{\circ} \mathrm{C}$. In fact, 
as it has been mentioned above, these high current densities are related to the oxidation of $\mathrm{TiO}$ and $\mathrm{Ti}_{2} \mathrm{O}_{3}$ to $\mathrm{TiO}_{2}[5,11,53,59]$ rather than to corrosion processes.

\section{CONCLUSIONS}

Ultrasonically induced cavitation was found to shift the Open Circuit Potential of titanium in the $992 \mathrm{~g} / \mathrm{l} \mathrm{LiBr}$ solution towards more negative values. Nevertheless, the electrode was not damaged after the OCP test, so this negative shift under cavitation does not mean that titanium was actively corroding, but that the metal surface was covered with a passive film which was thinner than under static conditions.

Cavitation had considerably more influence over the anodic branch than over the cathodic branch, which made the $E_{\text {corr }}$ be more negative and the $i_{c o r r}$ be six times higher under cavitation conditions than under static ones. Cavitation also increased the passive current density due to either the thinning of the passive film that covered the titanium surface or the enhancement of mass transport because of cavitation.

The repassivation time, $t_{r}$, was found to increase with increasing applied potentials. The parameter $n$, determined from the slopes of the $\log i(t)$ vs. $\log t$ representation was found to increase with decreasing applied potentials within the passive region of titanium in the $992 \mathrm{~g} / \mathrm{l} \mathrm{LiBr}$ solution, agreeing with the results obtained for $t_{r}$. At 0.1 , 0.3 and $0.5 \mathrm{~V} \mathrm{Ag} / \mathrm{AgCl}$, the values of $n$ were close to unity, indicating the formation of a solid and compact film following a high field mechanism. At $1 \mathrm{~V}_{\mathrm{Ag} / \mathrm{AgCl}}$ the value of $n$ was near 0.5 , which is usually attributed to the growth of a porous passive film by a dissolution-precipitation process. At 1.5 and $2 \mathrm{~V}_{\mathrm{Ag} / \mathrm{AgCl}}$ no repassivation was achieved. 
From the $\log i(t)$ vs $1 / q(t)$ plots it was demonstrated that repassivation kinetics of titanium in the $992 \mathrm{~g} / \mathrm{LiBr}$ solution at $0.1,0.3$ and $0.5 \mathrm{~V}_{\mathrm{Ag} / \mathrm{AgCl}}$ follow a Cabrera-Mott high field mechanism. The $c B V$ values obtained from the slope of those plots, which increased with increasing applied potentials, were in accordance with the other parameters used to study the repassivation behaviour, namely the repassivation time, $t_{r}$, and the repassivation index, $n$.

The total charge density consumed in the construction of the passive film after damaging it and the thickness of this new passive film are higher as the applied potential increases, from $0.1 \mathrm{~V}_{\mathrm{Ag} / \mathrm{AgCl}}$ to $1 \mathrm{~V}_{\mathrm{Ag} / \mathrm{AgCl}}$.

According to the results obtained for the quantification of the damage generated on titanium surface by cavitation, this damage seems not to be influenced by the applied potential since its order of magnitude is rather similar at the different applied potentials and analogous to the physical damage produced by cavitation in distilled water. The fact that titanium did not undergo pitting corrosion even at the highest applied potentials (1.5 and $\left.2 \mathrm{~V}_{\mathrm{Ag} / \mathrm{AgCl}}\right)$ may explain these results, since the damage generated by cavitation did not spread.

\section{ACKNOWLEDGEMENTS}

We wish express our gratitude to the Ministerio de Ciencia e Innovación (Project CTQ2009-07518), for the economical support of this research, to the Generalitat 
Valenciana for its help in the CLSM acquisition (MY08/ISIRYM/S/100), and to Dr. M. Asunción Jaime for her translation assistance.

\section{REFERENCES}

[1] S. Wu, I. W. Eames, Appl. Energy 66 (2000) 251-266.

[2] American Society of Heating, Refrigerating and Air-Conditioning Engineers (ASHRAE) Handbook, Absorption Cooling, Heating and Refrigeration Equipment (Refrigeration Volume), 2002.

[3] P. Srikhirin, S. Aphornratana, S. Chungpaibulpatana, Renew. Sust. Energ. Rev. 5 (2001) 343-372.

[4] K. E. Herold, R. Radermacher, S. Klein, Absorption Chillers and Heat Pumps, CRC Press, 1996.

[5] A. Igual-Muñoz, J. García-Antón, J. L. Guiñón, V. Pérez-Herranz, Corrosion 59 (2003) 606-615.

[6] J. L. Guiñón, J. García-Antón, V. Pérez-Herranz, G. Lacoste, Corrosion 50 (1994) $240-248$.

[7] E. A. Abd El Meguid, N. K. Awad, Corros. Sci. 51 (2009) 1134-1139.

[8] M. J. Muñoz-Portero, J. García-Antón, J. L. Guiñón, V. Pérez-Herranz, Corrosion 62 (2006) 1018-1027.

[9] D. Itzhak, O. Elias, Corrosion 50 (1994) 131-137.

[10] R.M. Fernández-Domene, E. Blasco-Tamarit, D. M. García-García, J. GarcíaAntón, Corros. Sci. 52 (2010) 3453-3464. 
[11] E. Blasco Tamarit, A. Igual Muñoz, J. García Antón, D. García García, Corros. Sci. 49 (2007) 1000-1026.

[12] G. Lutjering, J. C. Williams, Titanium (Engineering Materials and Processes), Springer, 2007.

[13] F. Hua, K. Mon, P. Pasupathi, G. Gordon, D. Shoesmith, Corrosion 61 (2005) 9871003.

[14] J. R. Birch, T. D. Burleigh, Corrosion 56 (2000) 1233-1241.

[15] J. F. Caron, M. Farhat, F. Avellan, $6^{\text {th }}$ international symposium on fluid control, measurements and visualization (Flucome 2000), Sherbrooke, USA, August (2000).

[16] J. P. Frank (Ed.), J. M. Michel (Ed.), Fundamentals of Cavitation, Kluwer Academic Publishers, $1^{\text {st }}$ edition, 2004.

[17] C. T. Kwok, F. T. Cheng, H. C. Man, Mater. Sci. Eng. A 290 (2000) 145-154.

[18] H. X. Guo, B. T. Lu, J. L. Luo, Electrochim. Acta 51 (2005) 315-323.

[19] C. H. Tang, F. T. Cheng, H. C. Man, Mater. Sci. Eng. A 373 (2004) 195-203.

[20] C. T. Kwok, F. T. Cheng, H. C. Man, Surf. Coat. Technol. 145 (2001) 206-214.

[21] S. Z. Luo, Y. G. Zheng, M. C. Li, Z. M. Yao, W. Ke, Corrosion 59 (2003) 597605.

[22] B. Vyas, I. L. H. Hansson, Corros. Sci. 30 (1990) 761-770.

[23] J. Liu, Y. Lin, X. Yong, X. Li, Corrosion 61 (2005) 1061-1069.

[24] D. M. García-García, J. García-Antón, A. Igual-Muñoz, E. Blasco-Tamarit, Corros. Sci. 48 (2006) 2380-2405. 
[25] W. Bao-Cheng, Z. Jin-hua, Ultrasonics Sonochemistry 15 (2008) 239-243.

[26] Y. G. Zheng, S. Z. Luo, W. Ke, Wear 262 (2007) 1308-1314.

[27] D. M. García García, J. García Antón, A. Igual Muñoz, Corros. Sci. 50 (2008) $2560-2571$.

[28] C. T. Kwok, H. C. Man, F. T. Cheng, Materials Science and Engineering A 303 (2001) 250-261.

[29] A. Neville, T. Hodgkiess, J. T. Dallas, Wear 186-187 (1995) 497-507.

[30] S. Z. Luo, Y. G. Zheng, M. C. Li, Z. M. Yao, W. Ke, Corrosion 59 (2003) 597605 .

[31] A. Neville, B. A. B. McDougall, Wear 250 (2001) 726-735.

[32] G. T. Burstein, P. I. Marshall, Corros. Sci. 23 (1983) 125-137.

[33] M. Barbosa, Corrosion 44 (1988) 149-153.

[34] G. T. Burstein, G. O. H. Whillock, J. Electrochem. Soc. 136 (1989) 1313-1319.

[35] S. Ahila, B. Reynders, H. J. Grabke, Corros. Sci. 38 (1996) 1991-2005.

[36] H. S. Kwon, E. A. Cho, K. A. Yeom, Corrosion 56 (2000) 32-40.

[37] E. A. Cho, C. K. Kim, J. -S. Kim, H. -S. Kwon, Electrochim. Acta 45 (2000) 1933-1942.

[38] S. J. Ahn, V. Shankar Rao, H. S. Kwon, U. C. Kim, Corros. Sci. 48 (2006) 1137 1153.

[39] R.M. Carranza, J.R. Galvele, Corros. Sci. 28 (1988) 233-249.

[40] F. M. Song, K. S. Raja, D. A. Jones, Corros. Sci. 48 (2006) 285-307.

[41] T. R. Beck, J. Electrochem. Soc. 115 (1968) 890-896. 
[42] T. R. Beck, J. Electrochem. Soc. 129 (1982) 2500-2501.

[43] J. J. Park, S. I. Pyun, W. J. Lee, H. P. Kim, Corrosion 55 (1999) 380-387.

[44] J. B. Lee, Mater. Chem. Phys. 99 (2006) 224-234.

[45] S. I. Pyun, E. J. Lee, Electrochim. Acta 40 (1995) 1963-1970.

[46] J. J. Park, S. I. Pyun, S. B. Lee, Electrochim. Acta 49 (2004) 281-292.

[47] W. J. Lee, S. I. Pyun, Electrochim. Acta 45 (2000) 1901-1910.

[48] G. T. Burstein, K. Sasaki, J. Electrochem. Soc. 148 (2001) B282-B287.

[49] P. R. Birkin, R. O’Connor, C. Rapple, S. Silva-Martínez, J. Chem. Soc., Faraday Trans. 94 (1998) 3365-3371.

[50] J. García-Antón, A. Igual-Muñoz, J. L. Guiñón, V. Pérez-Herranz, Spain, P$200002525,2000$.

[51] J. García-Antón, A. Igual-Muñoz, J. L. Guiñón, V. Pérez-Herranz, Spain, P$200002526,2000$.

[52] C. S. Brossia, G. A. Cragnolino, Corros. Sci. 46 (2004) 1693-1711.

[53] Y.Z. Huang, D.J. Blackwood, Electrochim. Acta 51 (2005) 1099-1107.

[54] H. Selcuk, J.J. Sene, M.V.B. Zanoni, H.Z. Sarikaya, M.A. Anderson, Chemosphere 54 (2004) 969-974.

[55] I. Dugdale, J.B. Cotton, Corros. Sci. 4 (1964) 397-411.

[56] N. Casillas, S. Charlebois, W.H. Smyrl, H.S. White, J. Electrochem. Soc. 141 (1994) 636-642.

[57] S.B. Basame, H. S. White, J. Electrochem. Soc. 147 (2000) 1376-1381.

[58] T.R. Beck, J. Electrochem. Soc. 120 (1973) 1310-1316.

[59] S. L. de Assis, S. Wolynec, I. Costa, Electrochim. Acta 51 (2006) 1815-1819. 
[60] M.J. Muñoz-Portero, J. García-Antón, J.L. Guiñón, R. Leiva-García, Corros. Sci. 53 (2011) 1440-1450.

[61] N.J. Laycock, R.C. Newman, Corros. Sci. 40 (1998) 887-902.

[62] M. Kaneko, H.S. Isaacs, Corros. Sci. 42 (2000) 67-78.

[63] S. Virtanen, C. Curty, Corrosion 60 (2004) 643-649.

[64] J.L. Trompette, L. Massot, L. Arurault, S. Fontorbes, Corros. Sci. 53 (2011) 12621268.

[65] S. Huo, X. Meng, Corros. Sci. 31 (1990) 281-286.

[66] S.B. Basame, H.S. White, J. Phys. Chem. 99 (1995) 16430-16435.

[67] J. D. Kim, S. I. Pyun, Electrochim. Acta 40 (1995) 1863-1869.

[68] Z. Szklarska-Smialowska, W. Kozlowski, J. Electrochem. Soc. 131 (1984) 234241.

[69] T. M. Angeliu, P. L. Andresen, M. L. Pollick, Corrosion 53 (1997)114-119.

[70] M. Stern, J. Electrochem. Soc. 106 (1959) 376-381.

[71] N. Cabrera, N.F. Mott, Rep. Prog. Phys. 12 (1948) 163.

[72] N. Sato, M. Cohen, J. Electrochem. Soc. 111 (1964) 512-519

[73] P. I. Marshall, G. T. Burstein, Corros. Sci. 23 (1983) 1219-1228.

[74] T. A. Adler, R. P. Walters, Corrosion 49 (1993) 399-409.

[75] H. A. Johansen, G. B. Adams, Jr., P. V. Rysselberghe, J. Electrochem. Soc. 104 (1957) 339-346.

[76] J. W. Park, V. S. Rao, H. S. Kwon, Corrosion 60 (2004) 1099-1103.

[77] D. R. Lide (Ed.), CRC Handbook of Chemistry and Physics, 89th ed., CRC Press, 2008.

[78] G. Bazanini, J. D. Bressan, Wear 263 (2007) 251-257. 
[79] S. M. Ahmed, Wear 218 (1998) 119-127.

[80] T. Momma, A. Lichtarowicz, Wear 186-187 (1995) 425-436.

[81] T. G. Leighton, The Acoustic Bubble, $1^{\text {st }}$ ed., Academic Press, 1994. 
Table 1

OCP values for titanium in the $992 \mathrm{~g} / 1 \mathrm{LiBr}$ solution under static $(p p A=0 \mu \mathrm{m})$ and cavitation $(p p A=120$ $\mu m$ ) conditions.

\begin{tabular}{|c|c|c|}
\hline \multicolumn{3}{|c|}{ OCP vs $(\mathrm{Ag} / \mathrm{AgCl}) / \mathrm{mV}$} \\
\hline$p p A=0 \mu \mathrm{m}$ & $p p A=120 \mu \mathrm{m}$ & $\Delta$ OCP \\
\hline$-75 \pm 4$ & $-986 \pm 48$ & 911 \\
\hline
\end{tabular}

Table 2

Electrochemical parameters for titanium in the $992 \mathrm{~g} / 1 \mathrm{LiBr}$ solution under static $(p p A=0 \mu \mathrm{m})$ and cavitation $(p p A=120 \mu m)$ conditions.

\begin{tabular}{|c|c|c|c|}
\hline & $\boldsymbol{E}_{\text {corr }} \mathbf{v s}(\mathbf{A g} / \mathbf{A g C l}) / \mathbf{V}$ & $\boldsymbol{i}_{\text {corr }} / \boldsymbol{\mu} \mathbf{A ~ \mathbf { ~ m } ^ { - 2 }}$ & $\boldsymbol{i}_{p} / \boldsymbol{\mu} \mathbf{A ~ \mathbf { ~ m } ^ { - 2 }}$ \\
\hline$p p A=0 \mu \mathrm{A}$ & $-0.149 \pm 0.06$ & $0.20 \pm 0.03$ & $1.94 \pm 0.03$ \\
\hline$p p A=120 \mu \mathrm{A}$ & $-1.248 \pm 0.04$ & $1.14 \pm 0.15$ & $2.94 \pm 0.3$ \\
\hline
\end{tabular}

Table 3

Repassivation times for titanium in the $992 \mathrm{~g} / \mathrm{LiBr}$ solution at $0.1,0.3,0.5$ and $1 \mathrm{~V} \mathrm{Ag} / \mathrm{AgCl}$.

\begin{tabular}{|c|c|}
\hline Potential vs $(\mathbf{A g} / \mathbf{A g C l}) / \mathbf{V}$ & $\boldsymbol{t}_{r} / \mathbf{s}$ \\
\hline 0.1 & 0.57 \\
\hline 0.3 & 0.36 \\
\hline 0.5 & 2.57 \\
\hline 1 & 16.02 \\
\hline
\end{tabular}

Table 4

Values of the parameter $n$, obtained from the linear region slope (stage 2) of $\log i(t)$ vs $\log t$ representation, for titanium in the $992 \mathrm{~g} / \mathrm{L} \mathrm{LiBr}$ solution, at the applied potentials of $0.1,0.3,0.5$ and 1 $\mathrm{V}_{\mathrm{Ag} / \mathrm{AgCl}}$. 


\begin{tabular}{|c|c|c|}
\hline Potential vs (Ag/AgCl)/V & $\boldsymbol{n}$ (Stage 2) & $\mathbf{R}$ \\
\hline 0.1 & $1.17 \pm 0.09$ & 0.96 \\
\hline 0.3 & $1.29 \pm 0.18$ & 0.96 \\
\hline 0.5 & $0.84 \pm 0.18$ & 0.97 \\
\hline 1 & $0.54 \pm 0.03$ & 0.99 \\
\hline
\end{tabular}

Table 5

Values of the parameter $c B V$, obtained from the linear region slope of $\log i(t) \mathrm{vs} 1 / q(t)$ plot, for titanium in the $992 \mathrm{~g} / \mathrm{l} \mathrm{LiBr}$ solution at those applied potential at which repassivation kinetics follow a high field mechanism ( $n$ value is close to unity).

\begin{tabular}{|c|c|c|}
\hline Potential vs (Ag/AgCl)/V & $\boldsymbol{c B} \boldsymbol{V} \cdot \mathbf{1 0} \mathbf{0}^{-4} / \mathbf{C}^{\mathbf{2}} \mathbf{c m}^{-\mathbf{4}} \mathbf{s}^{-\mathbf{1}}$ & $\mathbf{R}$ \\
\hline 0.1 & $0.918 \pm 0.02$ & 0.99 \\
\hline 0.3 & $1.03 \pm 0.15$ & 0.99 \\
\hline 0.5 & $1.35 \pm 0.07$ & 0.99 \\
\hline
\end{tabular}

Table 6.

Values of the total charge density $q(t)$ consumed during the repassivation process and estimated thickness of the newly formed passive film.

\begin{tabular}{|c|c|c|c|}
\hline Potential vs (Ag/AgCI)/V & $\boldsymbol{q}_{\infty} / \mathbf{m C ~}_{\mathbf{~ c m}} \mathbf{- n}^{-2}$ & $\boldsymbol{h}_{\infty} / \mathbf{n m}$ & $\boldsymbol{h}_{\circ} / \boldsymbol{h}_{\boldsymbol{m}}$ \\
\hline 0.1 & 0.32 & 15.74 & 50 \\
\hline 0.3 & 0.27 & 12.93 & 41 \\
\hline 0.5 & 0.91 & 43.97 & 141 \\
\hline 1 & 1.30 & 114.80 & 370 \\
\hline
\end{tabular}

Table 7.

Parameters of the damage generated by cavitation-corrosion on titanium surfaces in the $992 \mathrm{~g} / \mathrm{LiBr}$ solutions, at different applied potentials, and in distilled water (the values are mean values).

\begin{tabular}{|c|c|c|c|}
\hline $\begin{array}{l}\text { Potential vs } \\
(\text { Ag/AgCl)/V }\end{array}$ & Volume $/ \mathbf{m m}^{3}$ & Damaged Area $/ \mathbf{m m}^{2}$ & $\begin{array}{c}\text { Maximum depth } x \\
10^{3} / \mu \mathrm{m}\end{array}$ \\
\hline 0.1 & $2.27 \pm 0.4$ & $3.19 \pm 0.4$ & $1.10 \pm 0.008$ \\
\hline 0.3 & $2.29 \pm 0.7$ & $3.21 \pm 0.7$ & $1.02 \pm 0.08$ \\
\hline 0.5 & $2.01 \pm 0.2$ & $2.94 \pm 0.8$ & $0.95 \pm 0.04$ \\
\hline 1.0 & $2.03 \pm 0.6$ & $3.19 \pm 0.3$ & $0.89 \pm 0.1$ \\
\hline 1.5 & $2.80 \pm 0.3$ & $3.35 \pm 0.4$ & $1.02 \pm 0.02$ \\
\hline 2.0 & $1.71 \pm 0.3$ & $3.53 \pm 0.7$ & $0.97 \pm 0.4$ \\
\hline (*) & $2.18 \pm 0.4$ & $3.19 \pm 0.5$ & $0.94 \pm 0.2$ \\
\hline
\end{tabular}




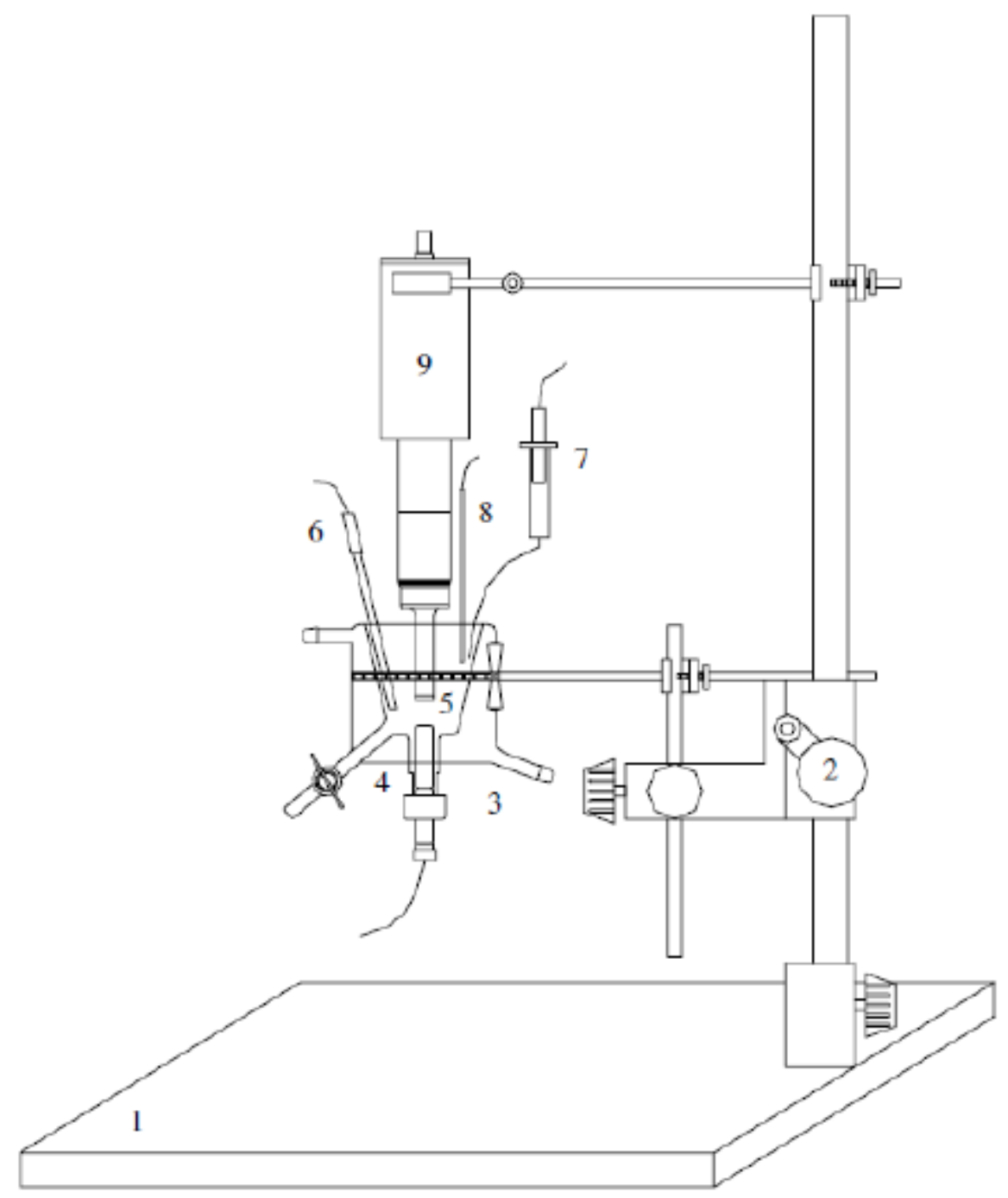

Fig. 1.

Experimental arrangement diagram used for cavitation testing: (1) base of experimental arrangement; (2) height adjustment; (3) electrochemical cell; (4) working electrode; (5) horn tip; (6) auxiliary electrode (platinum mesh); (7) reference electrode ( $\mathrm{Ag} / \mathrm{AgCl}$ with $3 \mathrm{M} \mathrm{KCl}$ solution); (8) temperature sensor; (9) convertor of ultrasonic cavitation facility. 


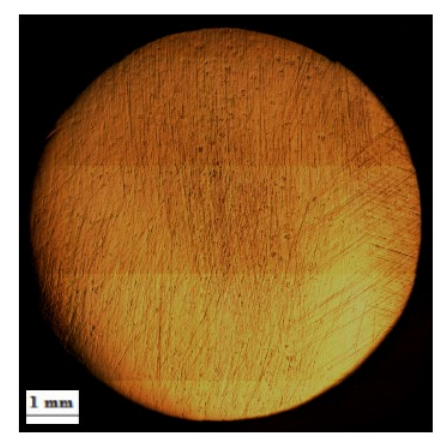

a. Initial conditions ( sample diameter $=8 \mathrm{~mm}$ )

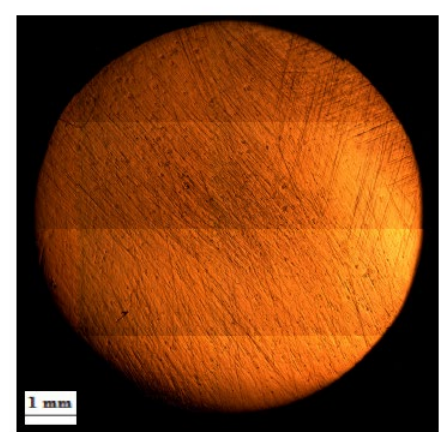

b. Final conditions $($ sample diameter $=8 \mathrm{~mm}$ )

Fig. 2.

Images of the electrode surface before (a) and after (b) the OCP test with cavitation.

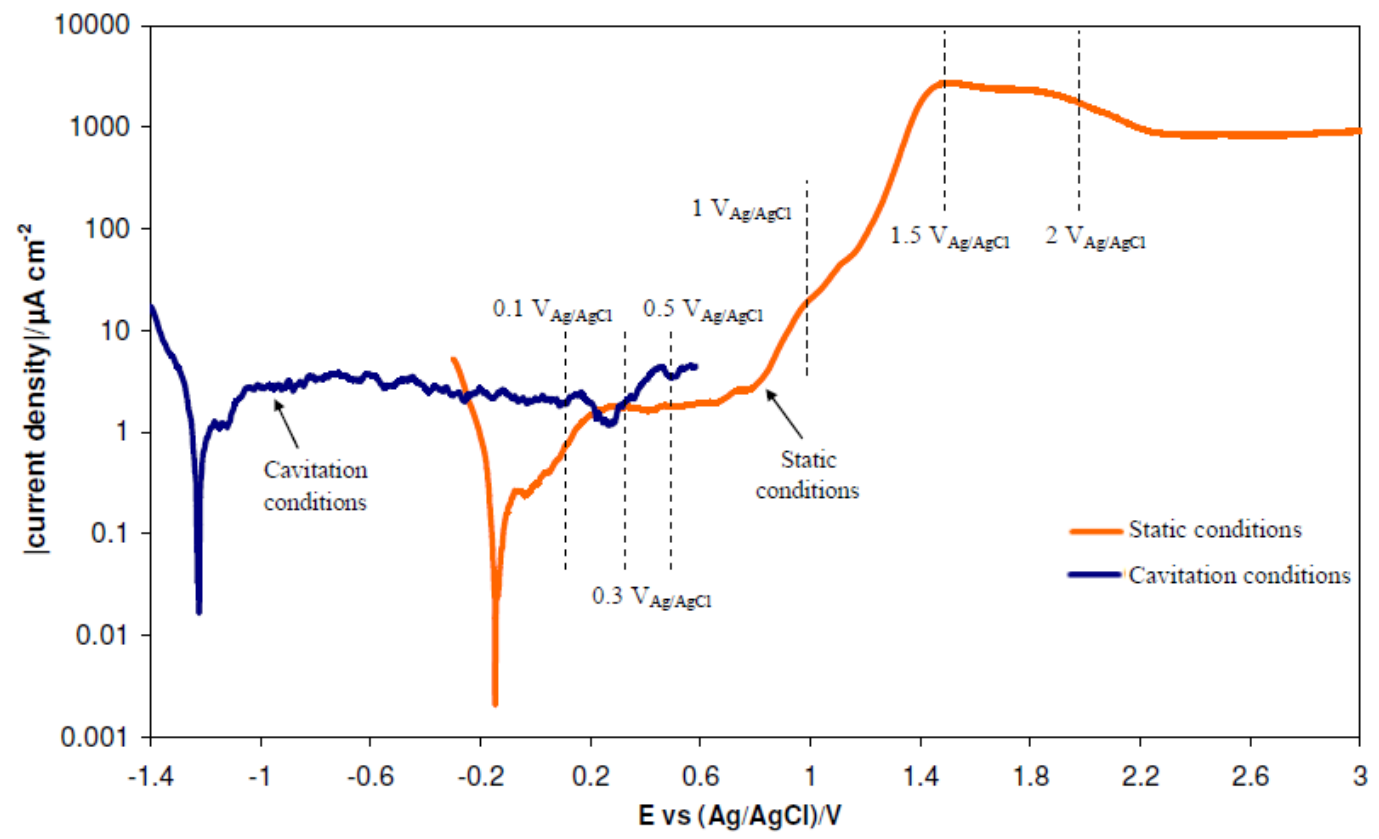

Fig. 3.

Potentiodynamic polarisation curves for titanium in $992 \mathrm{~g} / \mathrm{l} \mathrm{LiBr}$ solution under static and cavitation conditions. This figure also shows potentials chosen to perform the potentiostatic tests (on the curve under static conditions). 

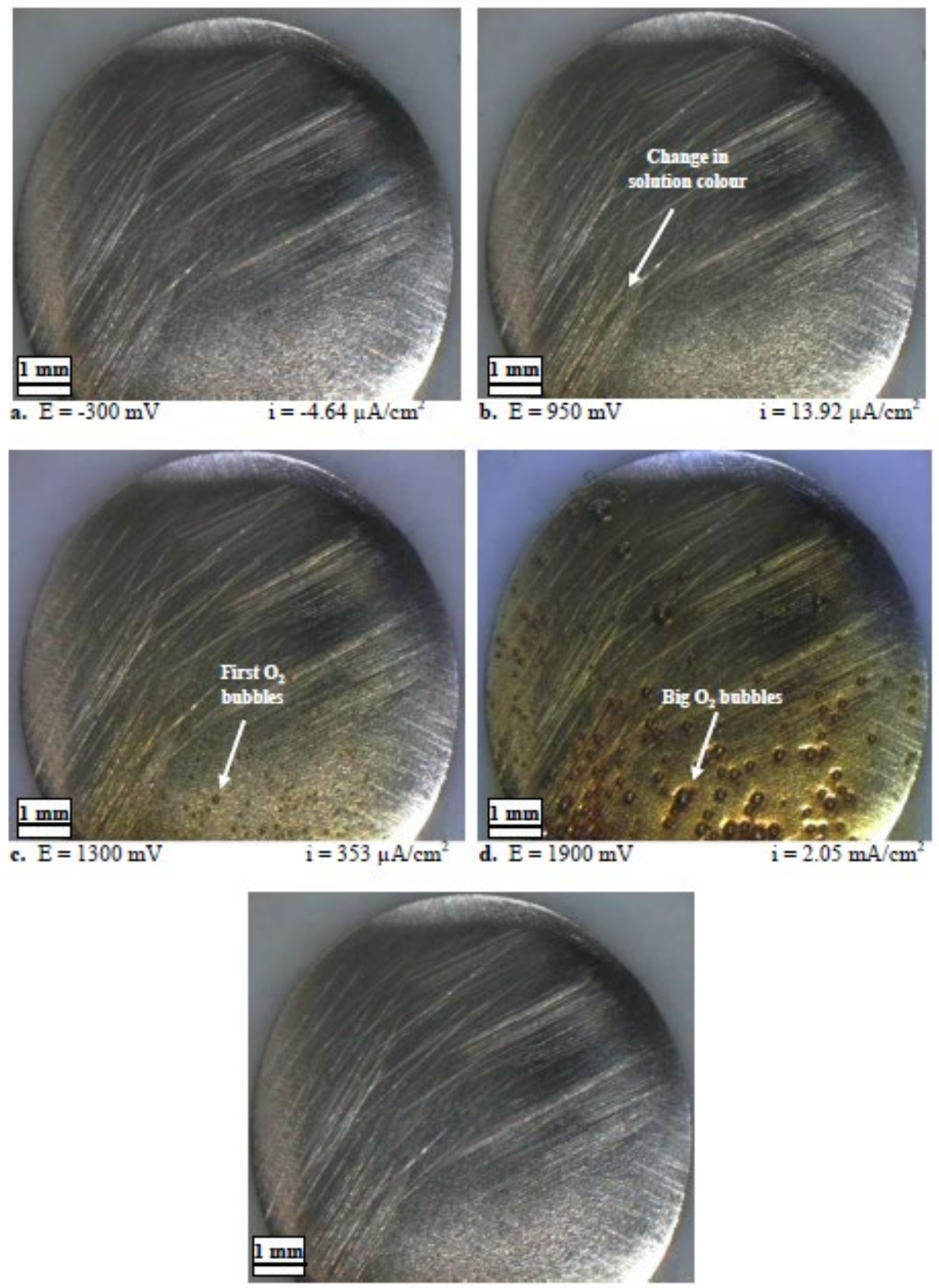

e. After rinsing the electrode with distilled water at the end of the test.

Fig. 4.

Images of titanium surface in the $992 \mathrm{~g} / \mathrm{LiBr}$ solution at different moments of the potentiodynamic test. 


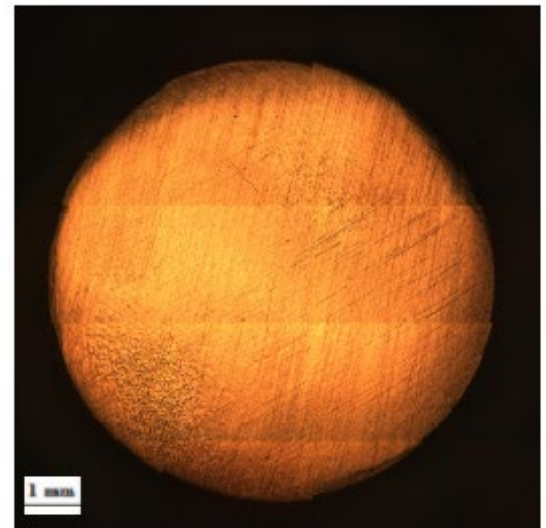

a. Initial conditions (sample diameter $=8 \mathrm{~mm}$ )

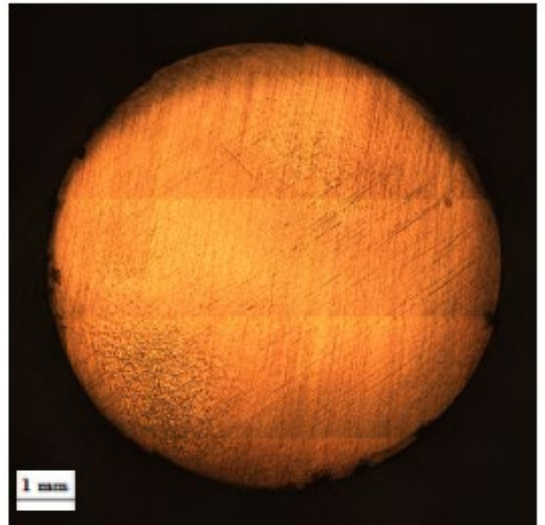

b. Final conditions (sample diameter $=8 \mathrm{~mm}$ )

Fig. 5.

Images of titanium electrodes in the $992 \mathrm{~g} / \mathrm{l} \mathrm{LiBr}$ solution before and after the potentiodynamic tests, under cavitation conditions (taken using a Confocal Laser Microscope). 

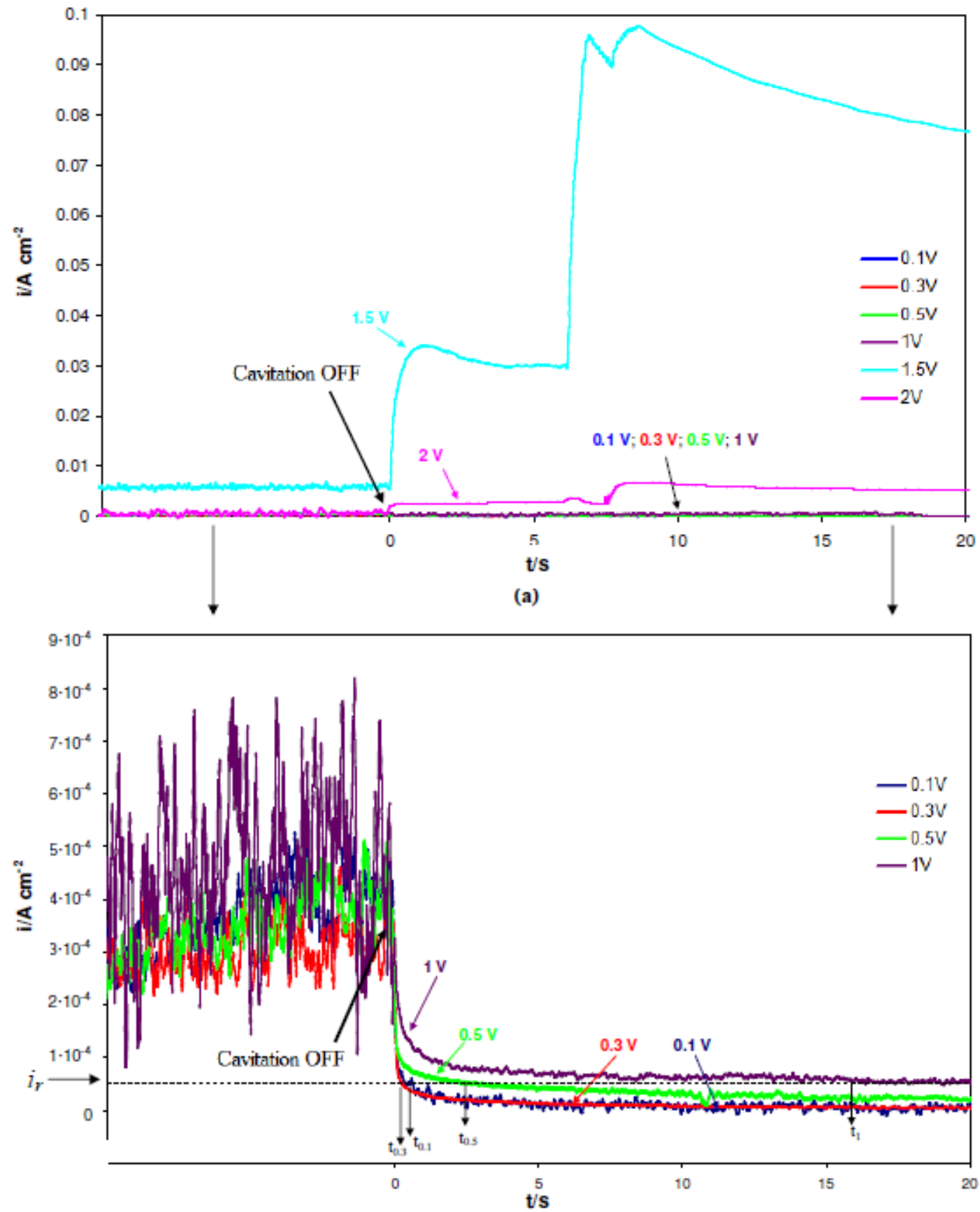

(b)

Fig. 6.

Current density transients in linear scale for titanium in the $992 \mathrm{~g} / \mathrm{l} \mathrm{LiBr}$ solution at the six selected potentials (from 0.1 to $2 \mathrm{~V}_{\mathrm{Ag} / \mathrm{AgCl}}(\mathrm{a}) ; 0.1,0.3,0.5$ and $1 \mathrm{~V}_{\mathrm{Ag} / \mathrm{AgCl}}$ (b)). 


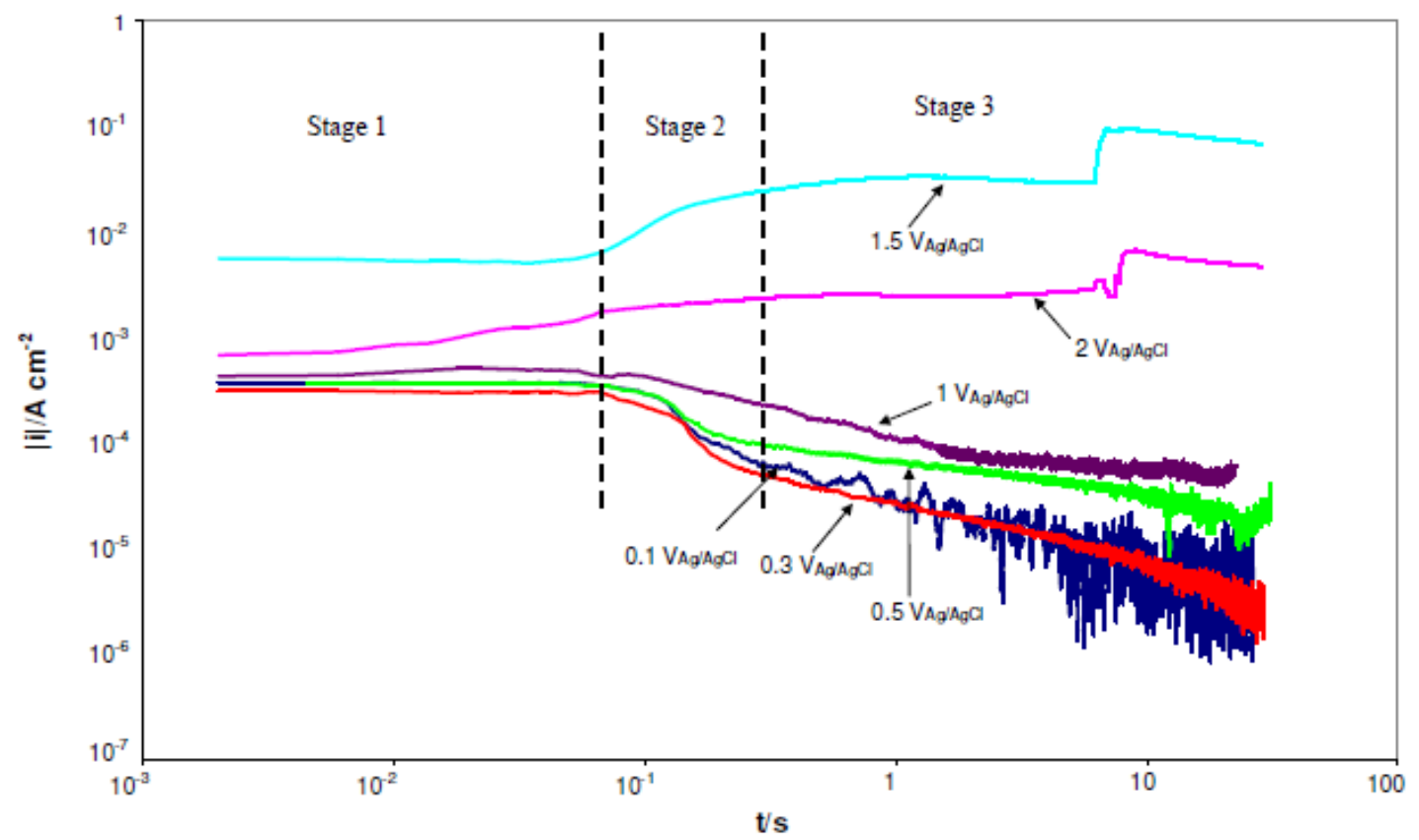

Fig. 7.

Plots of $i(t)$ vs $t$ in logarithmic scale obtained just after disconnecting cavitation, for titanium in the 992 $\mathrm{g} / \mathrm{l} \mathrm{LiBr}$ solution at the six chosen potentials.

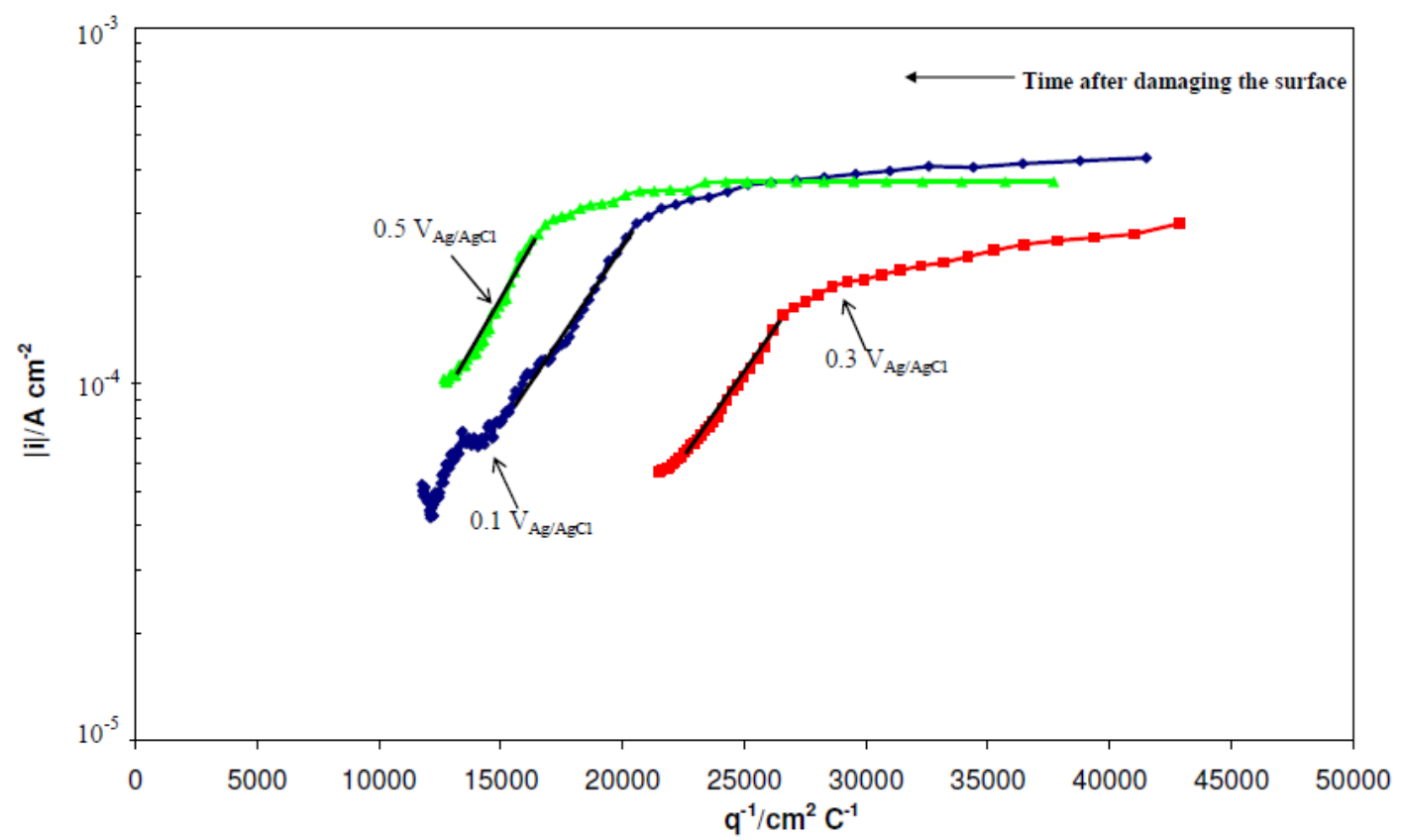

Fig. 8 .

Plots of $\log i(t)$ vs $q^{-1}$ according to the high field ion conduction model (eq. 6) for titanium in the $992 \mathrm{~g} / 1$ $\mathrm{LiBr}$ solution at $0.1,0.3$ and $0.5 \mathrm{~V} \mathrm{Ag} / \mathrm{AgCl}$. 


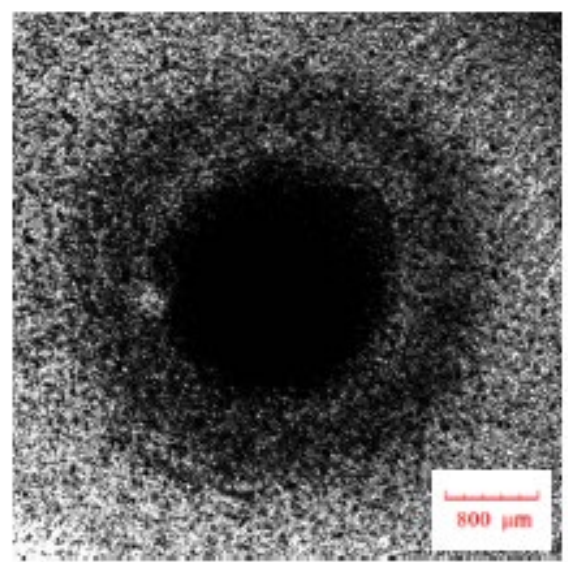

$0.1 \mathrm{~V}_{\mathrm{Ag} / \mathrm{AgCl}}$

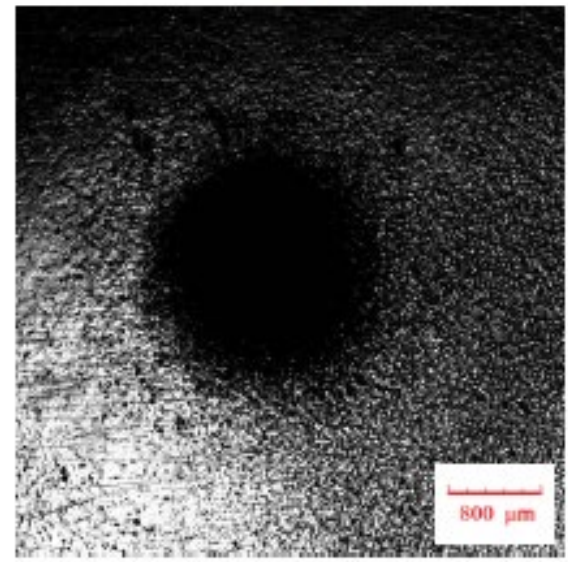

$1.5 \mathrm{~V} \mathrm{Ag} / \mathrm{AgCl}$

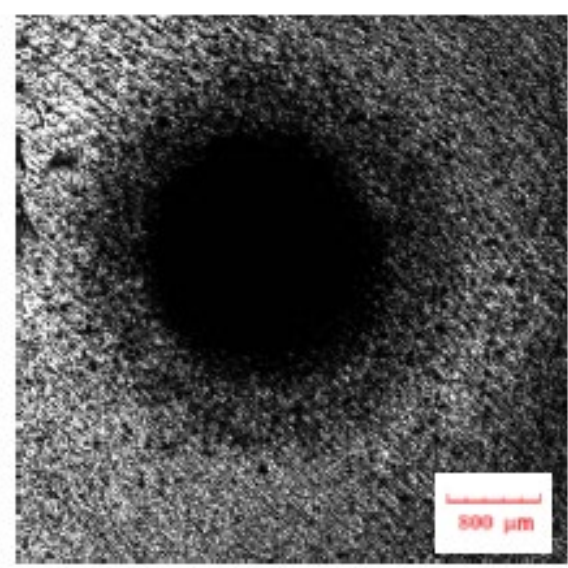

$1 \mathrm{~V}_{\mathrm{Ag} / \mathrm{AgCl}}$

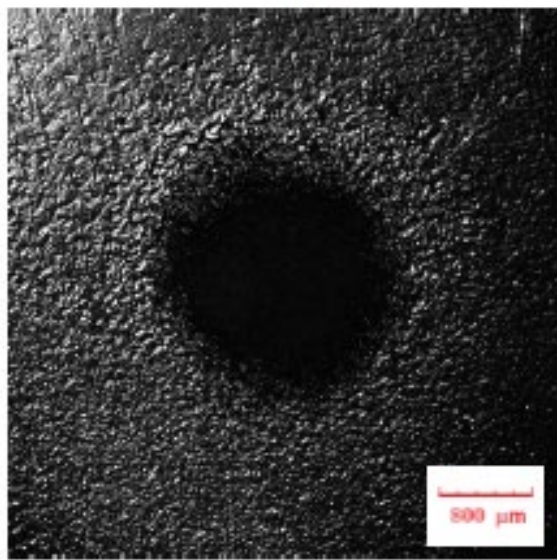

Distilled Water

Figure 9.

Micrographs of the damaged surfaces of titanium in the $992 \mathrm{~g} / 1 \mathrm{LiBr}$ solution at $0.1 \mathrm{~V}_{\mathrm{Ag} / \mathrm{AgCl}}, 1 \mathrm{~V} \mathrm{Ag} / \mathrm{AgCl}$, $1.5 \mathrm{~V}_{\mathrm{Ag} / \mathrm{AgCl}}$, and in distilled water. The micrographs were taken using the Confocal Laser Microscope. 